\title{
DELINEATION PROCESS OF THE EXTENDED CONTINENTAL SHELF: AN INTERPRETATION OF ARTICLE 76, PARAGRAPH 6, OF UNCLOS
}

\author{
PROCESO DE DELINEACIÓN DE LA PLATAFORMA CONTINENTAL \\ EXTENDIDA: UNA INTERPRETACIÓN DEL ARTÍCULO 76, \\ PARRAFO 6, DE CONVEMAR
}

Francisco Lertora Pinto*

\begin{abstract}
The 1982 United Nations Convention on the Law of the Sea established specific rules for the delineation of the outer limit of the continental shelf in Article 76. This Article contains two formulae and two constraints. Regarding these constraints, the coastal State can apply, whichever is more favorable to its claim, unless the exception established under Article 76 (6), first sentence, applies. This exception establishes that, on submarine ridges, the State can only apply the 350 nautical miles distance constraint. However, Article 76 (6), second sentence, introduces a counter-exception and preserves the State's right to apply either constraint when the seafloor high is a submarine elevation that is a natural component of the continental margin.
\end{abstract}

Keywords: UNCLOS; continental shelf beyond 200 nautical miles; seafloor highs; submarine elevations; submarine ridges.

RESUMEN: La CONVEMAR estableció reglas específicas para la delineación del límite exterior de la plataforma continental. El artículo 76 contiene dos fórmulas y dos restricciones. En relación con las restricciones, el Estado puede aplicar cualquiera de las dos, la que le sea más favorable, a menos que se aplique la excepción descrita en el Artículo 76 (6), primera parte. Dicha disposición, establece que cuando la elevación del fondo marino es una cresta submarina, el Estado solo puede aplicar la restricción de las $350 \mathrm{~mm}$. Sin embargo, el artículo 76 (6), segunda parte, introduce una contra excepción y preserva el derecho del Estado a aplicar cualquiera de las dos restricciones cuando la elevación del fondo marino es una elevación submarina que constituye un componente natural del margen continental.

Palabras clave: CONVEMAR; plataforma continental más allá de las 200 millas marítimas, elevaciones del fondo marino; elevaciones submarinas; crestas submarinas.

\section{INTRODUCTION}

The 1982 United Nations Convention on the Law of the Sea (hereinafter UNCLOS) sets out different provisions concerning the outer limits of the maritime spaces. Article 76 establishes substantial and procedural rules related to the delineation of the outer limit of the continental shelf beyond 200 nautical miles $(M)^{1}$.

\footnotetext{
Lawyer. Licenciado en Ciencias Juridicas y Sociales (Universidad de Chile). Assistant of Public International Law at the Law Faculty of Universidad de Chile. Orcid Code 0000-0001-8528-6930. Postal address: Las Garzas 6288, Las Condes, Santiago. Email: franciscolertora@gmail.com. This paper does not represent the official position of the Chilean State.

1 Art. 76 UNCLOS.
} 
Article 76 combines legal and scientific definitions, to provide the coastal States with the legal and technical bases for the establishment of the outer limit of their continental shelf beyond 200 M. However, Article 76 (1) clearly establishes that each coastal State will have ipso jure the legal minimum of $200 \mathrm{M}$ of continental shelf ${ }^{2}$.

The coastal State that wishes to establish a continental shelf beyond $200 \mathrm{M}$, shall submit information before the Commission on the Limits of the Continental Shelf (CLCS) to demonstrate that the natural prolongation of its submerged land territory to the outer edge of the continental margin extends beyond $200 \mathrm{M}$ (the so-called Appurtenance test). If the State is able to pass this test and demonstrate its entitlement to an extended continental shelf, it may proceed with the delineation of the outer limits of the continental shelf in accordance with the set of rules defined in Article 76, paragraphs 4 to $10^{3}$. These rules provide for a combination of two formulae and two constraints for the delineation of the outer limits of the continental shelf, as will be explained in the following sections. Based on the information provided by the coastal State and possibly several rounds of technical interchanges between the coastal State and the CLCS, the latter issues its recommendation on the establishment of the outer limit of the continental shelf, which shall be final and binding for the coastal State, according to the final sentence of paragraph 8 of Article $76^{4}$.

The purpose of this paper is to analyze the application of the depth constraint of 2500 meters isobath to different features of seafloor highs, especially, with regard to the situation of submarine ridges and submarine elevations that are natural components of the continental margin. The hypothesis of this paper is that when the coastal State can demonstrate that its seafloor high is a natural component of the continental margin, it will be considered as a submarine elevation, irrespective of the denomination of the feature such as a ridge and the State can apply both constraints. In the framework of UNCLOS three kinds of seafloor highs may be identified: submarine ridges, submarine elevations, and oceanic ridges. Oceanic ridges are specifically excluded from the continental margin under Article 76 (3), final part, that states that: "It [the continental margin] does not include the

\footnotetext{
2 Art. 76 (1) UNCLOS.

3 The CLCS has considered that "(i)f a State is able to demonstrate to the Commission that the natural prolongation of its submerged land territory to the outer edge of its continental margin extends beyond 200 nautical mile distance criterion, the outer limit of its continental shelf can be delineated by means of the application of the complex set of rules described in paragraphs 4 to 10 ". Point 2.2.3. of the Scientific and Technical Guidelines (STG) of the CLCS.

4 "The more convincing interpretation of 'final and binding' is that it refers only to the submitting state in that the submitting state, having delineated its outer limit of the continental shelf and that limit not being challenged by other states, cannot subsequently change the location of its outer limit. To this extent, and this extent only, would the outer limit be 'final and binding', not be contestable and perhaps become an obligation erga omnes. This interpretation of 'final and binding' is consistent with the political dynamic of ocean boundary-making and the real achievement of Article 76 which is that a claiming state cannot revisit its outer limit boundary", MCDorman (2002) p. 315. OudE ElfERINK has observed that: "It would, however, seem that the possibilities for objecting to outer limits which have been established on the basis of the recommendations of the Commission are more limited that would be the case for the maritime limits that have been established unilaterally by a coastal State. This is explained by the involvement of a treaty body -the CLCS- in the process leading up to the establishment of the outer limits of the continental shelf beyond 200 nautical miles by the coastal State. A court or tribunal would be competent to review the recommendations of the Commission in the framework of litigation between States", Oude Elferink (2009) p. 554.
} 
deep ocean floor with its oceanic ridges or the subsoil thereof"s. Thus, the seafloor high denominated "oceanic ridge" is not part of the continental margin and cannot be used by the coastal States for the establishment of the outer edge of the continental margin. As Judge Gao explains, "a seafloor high that has no geomorphological continuity with the landmass of a coastal state should be classified as an oceanic ridge in the sense of paragraph 3 of Article 76 whether or not it is formed of oceanic crust" ${ }^{\circ}$. On the other hand, the submarine ridges and submarine elevations are part of the continental margin. Thus, "a coastal State can define a submarine ridge as a ridge that is in morphological continuity with the continental margin and therefore is not located in the deep ocean floor, even though part of the ridge may differ geologically and genetically from the landmass of the coastal State. The fact that they are natural prolongations of land territory is one of the keys to distinguish submarine ridges from oceanic ridges"

This paper will therefore focus on the different treatment for submarine ridges and submarine elevations.

\section{THE ESTABLISHMENT OF THE OUTER LIMIT OF THE EXTENDED CONTINENTAL SHELF}

\section{Definition of Continental Shelf}

Article 76 (1) of UNCLOS defines the continental shelf as follows:

"The continental shelf of a coastal State comprises the seabed and subsoil of the submarine areas that extend beyond its territorial sea throughout the natural prolongation of its land territory to the outer edge of the continental margin, or to a distance of 200 nautical miles from the baselines from which the breadth of the territorial sea is measured where the outer edge of the continental margin does not extend up to that distance" .

According to this provision, the continental shelf could be defined either by the distance of $200 \mathrm{M}$ from the baselines or by the seabed and subsoil of the submarine areas that extend beyond its territorial sea throughout the natural prolongation of its land territory to the outer edge of the continental margin. The first one is a straightforward legal definition, whereas the latter incorporates complex scientific elements?

\footnotetext{
5 Art. 76 (3) UNCLOS.

6 GaO (2012) p. 126.

7 Basaran (2015) p. 6.

8 Art. 76 (1) UNCLOS.

9 A scholar states that the definition of the continental shelf "contains a range of geological and geomorphological terms. States may establish a continental shelf either based on distance (up to $200 \mathrm{~nm}$ ) or natural prolongation. The concept of prolongation recognizes the reasoning of the North Sea Continental Shelf case. However, the concept of prolongation can be used in both a geologic and a geomorphological sense", Mossop (2016) p. 70.
} 
The idea of a natural prolongation is not absolutely clear and is a disputed matter in the international law of the $\mathrm{sea}^{10}$. In the Bay of Bengal case, the International Tribunal for the Law of the Sea (hereinafter ITLOS) stated that, by contrast to the concept of the outer edge of the continental margin, "no elaboration of the notion of natural prolongation referred to in article 76, paragraph 1 , is to be found in the subsequent paragraphs. In this respect, the Tribunal recalls that, while the reference to natural prolongation was first introduced as a fundamental notion underpinning the regime of the continental shelf in the North Sea cases, it has never been defined"11.

However, that approach has been criticized $^{12}$. In his separate opinion, Judge Gao stated that " $[\mathrm{t}]_{\mathrm{o}}$ my regret, I cannot go as far as the Judgment does with regard to the interpretation of article 76 of the Convention. In my honest view, paragraph 1 of article 76 of the Convention, which is the controlling provision, defines the continental shelf and provides two bases for entitlement: natural prolongation and distance"13.

As a matter of international law, the interpretation of a treaty shall be done in the light of the Vienna Convention on the Law of Treaties (1969) (hereinafter VC), which in Article 31 (1) contains a general rule of interpretation:

"1. A treaty shall be interpreted in good faith in accordance with the ordinary meaning to be given to the terms of the treaty in their context and in the light of its object and purpose" 14 .

Under this umbrella provision ${ }^{15}$, Article 76 shall be interpreted as a whole. Therefore, the proper understanding of paragraph 1 of Article 76 requires an analysis of the rest of the paragraphs as well ${ }^{16}$. Indeed, Article 76 (1) defines, from a legal perspective, the continental shelf of a coastal State as the "natural prolongation of its land territory to the outer edge of the continental margin". Therefore, the "continental margin" and the "outer edge of the continental margin" are essentials for the interpretation of Article $76(1)^{17}$.

The continental margin is defined in Article 76 (3) as follows:

"The continental margin comprises the submerged prolongation of the land mass of the coastal State, and consists of the seabed and subsoil of the shelf, the slope and

10 "The definition of the continental shelf under paragraph 1 of Article 76 clearly refers to the principle of natural prolongation as the basis upon which a coastal state enjoys rights to its continental shelf. How the principle should be applied is not entirely obvious from the text alone". SuAREZ (2008) p. 139.

11 BANGLADESH V. MYANMAR (2012) para. 432.

12 Huang and Liao (2014) pp. 287-293.

13 Separate opinion of Judge Gao in BANGLADESH V. MYANMAR (2012) para. 88.

14 Art. 31 (1) VC.

15 Articles 31 and 32 reflect customary international law. The ICJ has in numerous cases observed that these articles are customary international law. In the case PERÚ V. CHILE, the ICJ stated that: "The Court is required to analyze the terms of the 1952 Santiago Declaration in accordance with the customary international law of treaty interpretation, as reflected in Articles 31 and 32 of the Vienna Convention on the Law of Treaties", para. 57.

16 Oude Elferink (2006) pp. 269-285.

17 Art, 76 (1) UNCLOS. 
the rise. It does not include the deep ocean floor with its oceanic ridges or the subsoil thereof" 18 .

According to Judge Gao in his separate opinion in the Bay of Bengal case, "[i]t follows that in order to be part of the natural prolongation of the land territory of a coastal state, a seafloor high must be part of the continental margin of the state in the sense that it constitutes 'the submerged prolongation of the land mass of the coastal State.' Similarly, if a seafloor high is part of the natural prolongation of the land territory of the coastal state, it must be part of the continental margin of the state" 19 .

The outer edge of the continental margin is stipulated in Article 76 (4) and consists of a set of rules for the establishment of the outer limit of the continental margin (the socalled formulae $)^{20}$, in connection with paragraphs 5 and $6^{21}$.

Thus, the continental shelf defined in Article 76 (1) is a legal concept and shall be interpreted in the context of paragraphs 3 (which is a scientific approach) and 4 to $6^{22}$. As a consequence, the continental shelf does not necessarily match with the continental margin since the latter is the submerged prolongation of the coastal State including the seabed and subsoil of the shelf, the slope and the rise, excluding the deep ocean floor with its oceanic ridges; while the continental shelf is the natural prolongation of its land territory (of the coastal State) to the outer edge of the continental margin ${ }^{23}$. The location of the outer edge of the continental margin may not coincide with the area of the continental margin.

\section{The Institution of the Continental Shelf: natural prolongation or DISTANCE}

In the Aegean case, the International Court of Justice (ICJ) summarized the continental shelf doctrine, and pointed out that:

"The reason is that legally a coastal State's rights over the continental shelf are both appurtenant to and directly derived from the State's sovereignty over the territory abutting on that continental shelf. This emerges clearly from the emphasis placed by the Court in the North Sea Continental Shelf cases on 'natural prolongation' of the land as a criterion for determining the extent of a coastal State's entitlement to continental shelf as against other States abutting on the same continental shelf [...] As the Court explained in the above-mentioned cases, the continental shelf is a legal concept in which 'the principle is applied that the land dominates the sea' [...] and it is solely by virtue of the coastal State's sovereignty over the land that rights of ex-

\footnotetext{
18 Art. 76 (3) UNCLOS.

19 GAO (2012) p. 120. He explains that the oceanic ridge cannot be used for the establishment of the outer edge of the continental margin because is not part of the natural prolongation of the coastal State.

20 Art. 76 (4) UNCLOS.

21 Art. 76 (5) and (6) UNCLOS.

22 Art. 76 (1), (3), (4) and (6) UNCLOS.

23 Kunoy (2011) p. 316; Magnússon (2013) p. 346.
} 
ploration and exploitation in the continental shelf can attach to it, ipso jure, under international law. In short, continental shelf rights are legally both an emanation from and an automatic adjunct of the territorial sovereignty of the coastal State. It follows that the territorial régime -the territorial status- of a coastal State comprises, ipso jure, the rights of exploration and exploitation over the continental shelf to which it is entitled under international law. A dispute regarding those rights would, therefore, appear to be one which may be said to 'relate' to the territorial status of the coastal State" 24 .

Coastal State entitlement to the continental shelf is based on the principle that "land dominates the sea" 25 , but the natural prolongation must be established by scientific evidence. In this sense, "a coastal State's proposed outer limits of the continental shelf presupposes that the entire continental shelf from the territorial sea onwards to its outer limits is a natural prolongation of its land territory" 26 .

In the Bay of Bengal Judgment, ITLOS pointed out: "Thus the notion of natural prolongation and that of continental margin under article 76, paragraphs 1 and 4, are closely interrelated. They refer to the same area" ${ }^{27}$. This explanation is correct and shows a contradiction with its previous analysis. Therefore, ITLOS seems to confuse two different situations: on the one hand, the concept of the continental shelf and the entitlement of the coastal States to the extended continental shelf (Article 76 [1] and [3]); and, on the other hand, the operation for the delineation of the continental shelf, especially, the establishment of the outer edge of the continental margin (Article 76 [4] $)^{28}$.

Therefore, the natural prolongation is the entitlement of a coastal State on the continental shelf beyond $200 \mathrm{M}^{29}$.

Delineation is a parallel process within the competence of the CLCS, while the delimitation process is within the competence of the international tribunals ${ }^{30}$.

The above has been clarified by ITLOS in Bay of Bengal Judgment where it stated:

"There is a clear distinction between the delimitation of the continental shelf under article 83 and the delineation of its outer limits under article 76. Under the latter article, the Commission is assigned the function of making recommendations to coastal States on matters relating to the establishment of the outer limits of the con-

24 GREECE V. TURKEY (1978) para. 86.

25 GeRmany V. DENMARK; GeRMANY V. NETHERLAND (1969) para. 96.

26 Kunoy (2011) p. 322.

27 BANGLADESH V. MYANMAR (2012) para. 434.

28 JENSEN (2018) p. 356.

29 "[...] namely that the rights of the coastal State in respect of the area of continental shelf that constitutes a natural prolongation of its land territory into and under the sea exist ipso facto and ab initio, by virtue of its sovereignty over the land, and as an extension of it in an exercise of sovereign rights for the purpose of exploring the seabed and exploiting its natural resources". GERMANY V. DENMARK; GERMANY V. NETHERLAND (1969), para. 19.

30 Magnússon (2013a) pp. 482-483. 
tinental shelf, but it does so without prejudice to delimitation of maritime boundaries. The function of settling disputes with respect to delimitation of maritime boundaries is entrusted to dispute settlement procedures under article 83 and Part $\mathrm{XV}$ of the Convention, which include international courts and tribunals" ${ }^{\prime 3}$.

The same distinction was made by the ICJ in the Nicaragua v. Colombia and Somalia v. Kenia cases ${ }^{32}$. A scholar has stated: "on constate une certaine réticence de la Cour international de Justice à faire référence explicite à l'arrêt relative au Golfe du Bengale dans ses décisions récentes" ${ }^{33}$. Nevertheless, the ICJ has clearly taken into account, at least implicitly, the Bay of Bengal Judgment in these two cases.

The continental shelf may coincide with the Exclusive Economic Zone (EEZ), but they are definitely not the same. In this regard, in the case between Libya and Malta, the ICJ stated:

"Although there can be a continental shelf where there is no exclusive economic zone, there cannot be an exclusive economic zone without a corresponding continental shelf. It follows that, for juridical and practical reasons, the distance criterion must now apply to the continental shelf as well as to the exclusive economic zone; and this quite apart from the provision as to distance in paragraph 1 of Article 76. This is not to suggest that the idea of natural prolongation is now superseded by that of distance" ${ }^{34}$.

This paragraph is commented by professor Tanaka as follows: "In light of the dictum of the Court and Article 76 of the LOSC, it may be argued that currently the distance criterion is the real title over the continental shelf up to 200 nautical miles and the natural prolongation offers legal title over the shelf beyond 200 nautical miles" 35.

This should not be misinterpreted as establishing two separate institutions: an inner and an outer continental shelf. Such division was rejected by the Arbitral Tribunal in the case Barbados v. Trinidad and Tobago, when the Tribunal pointed out that "in any event

\footnotetext{
31 Bangladesh V. MYANMAR (2012) para. 376. The same Tribunal in the case: GHANA V. Côte D'IVOIRE (2017) para. 493.

32 In Somalia V. KENYA case, Preliminary Objections (2017), para. 67, the ICJ pointed out that: "As the Court has recently observed, "the role of the CLCS relates only to the delineation of the outer limits of the continental shelf, and not delimitation" [...] The two tasks are distinct [...] and the delimitation of the continental shelf "can be undertaken independently of a recommendation from the CLCS" [...] In this respect, Article 76, paragraph 10, of UNCLOS provides that " $[\mathrm{t}]$ he provisions of this article are without prejudice to the question of delimitation of the continental shelf between States with opposite or adjacent coasts". Nonetheless, as the Court has highlighted, "it is possible that the two operations may impact upon one another" and the rules of the CLCS therefore contain provisions that seek "to ensure that its actions do not prejudice matters relating to delimitation".

33 GESLIN (2018) p. 213.

34 LIBYAN ARAB JARNAHIRIYA V. MALTA (1985) para. 34.

35 TANAKA (2012) p. 135.
} 
there is in law only a single 'continental shelf' rather than an inner continental shelf and a separate extended or outer continental shelf" 36 .

Hence, the natural prolongation and distance criteria are essential elements in the concept of the continental shelf ${ }^{37}$. However, it should be borne in mind that Article 76 (1) of UNCLOS states that the coastal States' entitles to the continental shelf are the natural prolongation or the distance ${ }^{38}$. This suggests that there are two alternative criteria since the disjunction "or" reflects an alternative criterion rather than a complementary criterion.

Nevertheless, in the case Libya v. Malta, the ICJ stated that both criteria "are not opposed but complementary" 39 . The application of the entitlement based in the natural prolongation criterion will be important when the coastal State has a natural prolongation of its submerged land territory to the outer edge of the continental margin extends beyond 200 $\mathrm{M}^{40}$. If it is not the case, the coastal State will have the legal entitlement of the distance ${ }^{41}$.

In addition, in the case Libya v. Malta there was a dissenting opinion about this issue. Judge Oda stated that Article 76 (1) established "two radically alternative definitions" ${ }^{\prime 2}$. In similar terms, in the case Tunisia v. Libya, Judge Jiménez de Aréchaga observed that "the alternative 200-mile definition is obviously made independent of the criterion of natural prolongation: in the second part of the formula, after the word or, the requirement of 'natural prolongation' ceases to apply" 43.

This matter could be of a cardinal importance in the context of an outer continental shelf delimitation. As Colson has said: "the consolidated law of maritime boundary delimitation is secure, but after a hiatus since 1985, geological and geomorphological factors will reemerge in the law of maritime delimitation of the outer continental shelf" 44 .

In the frame of this debate the question of whether there is a hierarchy between the distance and natural prolongation criteria could arise. The answer to this question is a mat-

36 BARBADOS V. TRINIDAD AND TOBAGO (2006) para. 213.

37 LIBYA V. MALTA (1985) para. 34.

38 It should be borne in mind that the natural prolongation can play an important role in two spheres: A) The entitlements of the coastal State to the continental shelf. B) As a relevant circumstance for the delimitation of the continental shelf. A scholar states that: "The issue of natural prolongation as a relevant circumstance must be separated off from the discussion of natural prolongation as a basis of title”. Evans (2018) p. 249.

39 LIBYA V. MALTA (1985) para. 34.

40 It should be noted the difference between the entitlement and title. About this issue, professor KunOY states that "entitlement to the continental shelf corresponds to coastal States' maximum potential geographical extent of jurisdiction, while title corresponds to the area landward the boundaries which the relevant judicial or arbitral forum declares". KunOY (2013) p. 65.

41 "The legislative history of UNCLOS III shows that the two types of juridical continental shelf that emerged in paragraph 1 were results of a compromise arrived at in the Second Committee". SuAREz (2008) p. 139.

42 LiBYA V. MALTA (1985), dissenting opinion of Judge Oda, para. 61.

43 Tunisia V. Libyan ARAB JamahiriYa (1982), dissenting opinion of Judge Jiménez de Aréchaga, para. 51.

44 Colson (2003) p.107. However, in Bay of Bengal case, the geomorphology and geology alleged by Bangladesh were not considered by ITLOS as a relevant circumstance for the shift or adjustment of the equidistance line in the maritime boundary delimitation process in the area of the outer continental shelf. 
ter of discussion in scholarship, and we have no pronouncement of an international tribunal about this topic so far ${ }^{45}$. However, this merits the following commentaries:

At this point, a problem arises when an outer continental shelf of one State is within the $200 \mathrm{M}$ of the continental shelf of another State ${ }^{46}$. This situation has been advanced by Nicaragua, where its outer continental shelf is within the inner continental shelf of Colombia ${ }^{47}$.

The maritime delimitation methodology of the three-steps approach is difficult to apply in these cases because the equidistance line may not be located ${ }^{48}$, for geometrical considerations, in the area where there are overlapping continental shelf claims ${ }^{49}$. For the above reason, Nicaragua required the ICJ to divide the overlapping area between its outer continental shelf and the continental shelf of Colombia within its $200 \mathrm{M}$ by application of

45 This topic is discussing in the case NiCARAGUa V. Colombia (2016) before the ICJ (Question of the Delimitation of the Continental Shelf between Nicaragua and Colombia beyond 200 Nautical Miles from the Nicaraguan Coast).

46 Professor Colson seems to support the thesis that the distance entitlement of $200 \mathrm{M}$ cannot be jeopardized by the natural prolongation entitlement. In this sense, he gives the following example: "Assume that countries A and B are opposite and 500 nautical miles apart. Each maintains a 200-nautical-mile zone claim; thus, a 100- nautical-mile strip lies between these two zones. Furthermore, assume that country A has a very narrow continental shelf, which drops off to the deep seabed within 75 nautical miles of the coast. Country B, however, is a broad margin state. Its continental shelf (in the terms of Article 76) actually extends through its 200-nautical-mile zone, the entire 100-nautical-mile strip, and into the 200-nautical-mile zone of country A. In such a situation, in concept, the law seems to provide (1) that country A is entitled to its entire 200-nautical-mile zone, including the portion of outer continental shelf attributable to country $\mathrm{B}$ that intrudes into its 200-nautical-mile zone; but (2) that country A is not entitled to any of the outer continental shelf in the 100nautical-mile strip, as that is attributable solely to country B”. COLSON (2003) p. 103.

47 In the Preliminary Objections of Colombia (2014), NICARAGUA V. COLOMBIA (2012), pending case, was included as Figure 5, the shape presented by Nicaragua in its Reply (Figure 3-11) in the NICARAGUA V. COLOMBIA (2012). In that figure, Nicaragua represented the overlapping area of the continental shelf with the following text: "Line of equal division of area of overlapping margins". Thus, Nicaragua is not thinking in applying an equidistance line, but a median line that will be an apportion of the area of overlapping entitlements.

48 Colson (2003) p. 103: "For example 3, however, what if the foot of the slope of country A were located 220 nautical miles from the coast of country A, and the foot of the slope of country B were located 180 nautical miles from the coast of country B? Would this fact be relevant in dividing the sediment basin between countries $\mathrm{A}$ and $\mathrm{B}$ ? Rather than an equidistant line as measured from the coasts, as in example 2, would a more equitable solution (in keeping with the basis of title over the outer continental shelf) be to establish a median line between two lines marking each foot of the respective continental slopes, which in this case would create an outer continental shelf boundary 270 nautical miles from country A and 230 nautical miles from country B?". It should be borne in mind that in this example of professor Colson the area of overlapping titles is located beyond $200 \mathrm{M}$ from both States, in a strip of $100 \mathrm{M}$ between the States. However, the solution could be applied mutatis mutandis when the area under dispute is located into the $200 \mathrm{M}$ of one State, which is the solution proposed by Nicaragua. But if the distance criterion prevails over the natural prolongation is not possible to apply this solution because the outer continental shelf of one State will not be able to cross into the $200 \mathrm{M}$ of another State.

49 The three-steps approach in the maritime delimitation consists in the following stages: First, the tribunal draws a provisional equidistance line; second, the tribunal takes into account the relevant circumstances that may or may not adjust or shift the provisional equidistance line; and finally, the tribunal applies the disproportionality test. See: ROMANIA V. UKRAINE (2009) pp. 115-122. 
an "equal division", namely, an apportion of the area under dispute, since an equidistance line cannot be applied under the three-steps methodology ${ }^{50}$.

In point of fact, there is no jurisprudence (precedents) about this issue, but we think that the situation here is not only a problem of maritime delimitation methodology; it is a problem of the hierarchy between the natural prolongation and distance entitlements. If the Court holds the idea that the natural prolongation is the prevalence criterion, we think that the maritime delimitation methodology should be subordinate to the legal titles that will be declared, and not the opposite.

Thus, it would not be strange if the ICJ accepts the delimitation approach proposed by Nicaragua in the hypothesis that the natural prolongation has a preference over the distance entitlement. Of course, if the ICJ holds that the distance prevails over the natural prolongation this discussion c'est fini.

\section{THE APPLication OF THE FORMUlaE}

If the coastal State can prove that the natural prolongation of its submerged land territory to the outer edge of the continental margin extends beyond $200 \mathrm{M}$, it is entitled to claim an extended continental shelf. If no such proof has been provided, the coastal State will still automatically be entitled to $200 \mathrm{M}$ of continental shelf by application of Article $76(1)^{51}$.

When the coastal State is entitled to an extended continental shelf, it shall apply the rules contained in paragraph 4 for the establishment of the outer edge of the continental margin. Article 76 (4) states as follows ${ }^{52}$ :

"(a) For the purposes of this Convention, the coastal State shall establish the outer edge of the continental margin wherever the margin extends beyond 200 nautical miles from the baselines from which the breadth of the territorial sea is measured, by either:

"(i) a line delineated in accordance with paragraph 7 by reference to the outermost fixed points at each of which the thickness of sedimentary rocks is at least 1 per cent of the shortest distance from such point to the foot of the continental slope; or

"(ii) a line delineated in accordance with paragraph 7 by reference to fixed points not more than 60 nautical miles from the foot of the continental slope".

\footnotetext{
50 A scholar has stated that: "Le débat relatif à l'applicabilité de la règle de l'équidistance/circonstances pertinentes à une délimitation portant sur le plateau continental étendu est en partie un retour vers le passé [...] La définition du plateau continental á travers des critères géographiques et géologiques á l'article 76 de la CMB jetait aussi quelques doutes sur l'applicabilité de la règle de l'équidistance/circonstances pertinentes à une délimitation portant sur cette espace puisque l'idée du prolongement y a fait son retour triomphal". Von MUHLENDAHL (2016) pp. 372 and 387. 1) In the Bay of Bengal case the distance criterion and the three-steps methodology were useful, but the situation with the opposite States is different and that methodology could result useless for those maritime delimitations. 2) The outer continental shelf delimitation is not based in the distance criterion but in the natural prolongation. Thus, geological and geomorphological factors could be taken into account by an international tribunal.

51 Art. 76 (1) UNCLOS.

52 Art. 76 (4) UNCLOS.
} 
The identification of the Foot of the Continental Slope (FOS) is an essential step in the establishment of the outer edge of the continental margin together with the identification of the Base of the Continental Slope (BOS) region, since " $[\mathrm{t}]$ he foot and the base of the continental slope are inseparable, and commonly lie close to the outer edge of the continent, that is, near the place where the crust changes from continental to oceanic", according to the Commission ${ }^{53}$.

It should be observed that if the coastal State does not identify its FOS in accordance with the above rules, it will not be entitled to an extended continental shelf. In fact, "it should be noted that the foot of the continental slope is in effect the continental shelf baseline' to the area beyond $200 \mathrm{M}$. In the absence of a foot of the continental slope which permits the outer edge of the continental margin to be established beyond $200 \mathrm{M}$, there is no entitlement to the continental shelf beyond $200 \mathrm{M} " 54$.

In this line, the recommendations of the CLCS to the United Kingdom regarding Ascension Island, pointed out that:

"The Commission recognises the entitlement of a coastal State to delineate the outer limits of the continental shelf beyond $200 \mathrm{M}$ if the outer edge of the continental margin established from FOS points determined at its base by applying the provisions of article 76, paragraph 4, extend beyond the coastal State's $200 \mathrm{M}$ limits [...] Whether such islands are entitled to establish outer limits to their continental shelves beyond $200 \mathrm{M}$ depends on the location of the base and the FOS within the submerged prolongation of those islands. Therefore, the FOS must be situated more than $140 \mathrm{M}$ from the territorial sea baselines in order to establish an outer edge of continental margin beyond $200 \mathrm{M}$ using the $60 \mathrm{M}$ distance formula" ${ }^{\text {". }}$.

Hence, when the continental shelf of the coastal State extends beyond $200 \mathrm{M}$, the coastal State shall establish the outer edge of the continental margin by application of either of two formulae: A) The 1 per cent sediment thickness formula. B) Application of the FOS plus $60 \mathrm{M}$ formula ${ }^{56}$.

For the determination of FOS points, Article 76 (4) (b) states the following:

\footnotetext{
53 Point 6.2 .3 of the STG of the CLCS.

${ }^{54}$ KUnOY (2013) p. 72. A scholar has stated that: "The main argument supporting this view is that it is the FOS, not the coast, which is the main factor with regard to entitlement that leads to the establishment of the outer limits of the continental shelf beyond $200 \mathrm{~nm}$. The reason why a state would be interested in using the FOS as the reference line instead of the territorial sea baselines is that, in some instances, a state would get a larger slice of the disputed area in question by using the FOS as the basis for a provisional equidistance line". Magnússon (2014) p. 45.

55 Recommendations of the CLCS in regard to the Submission made by the United Kingdom of Great Britain and Northern Ireland in respect of Ascension Island, paragraphs 28 and 44.

56 The CLCS has interpreted this provision as " $t]$ he use of an inclusive disjunction as a connective between the two formulae implies that the compound is true so long as at least one of the components is true. Thus, the limit of the continental shelf can be extended up to 1 per cent sediment thickness line delineated by reference to fixed points, or to line delineated by reference to fixed points at a distance of 60 nautical miles from the foot of the continental slope, or both". Point 2.1.5. of the STG of the CLCS.
} 
"In the absence of evidence to the contrary, the foot of the continental slope shall be determined as the point of maximum change in the gradient at its base" 57 .

Thus, the general rule for the determination of the FOS is the point of maximum change in the gradient at its base. To determine the point of maximum change, the coastal State shall submit bathymetric and geological information.

Article 76 (4) (b) provides for an exception to this general rule, which requires the presentation of "evidence to the contrary".

The evidence to the contrary, according to the Commission, can be used not only when the coastal State cannot prove the location of the FOS, but in all cases when the State wants to complement the information of the correct location of its FOS. According to the Commission, "the determination of the foot of the continental slope when evidence to the contrary to the general rule is invoked, as a provision with the character of an exception to the rule. This provision not only does not oppose, but in fact complements, the general rule established by the determination of the foot of the continental slope as the point of maximum change in the gradient at its base" 58 .

In the context of the seafloor highs, the FOS cannot be used in the case of a submarine ridge to extend the continental shelf beyond $350 \mathrm{M}$, since the submarine ridge is subject to the distance constraint and not to the depth constraint such as will be studied in the following sections. On the contrary, if the coastal State demonstrates that its seafloor high is a submarine elevation that is a natural component of the continental margin the State can use the FOS plus 60 formula and exceed the $350 \mathrm{M}$ because the coastal State is able to apply the depth constraint.

Together with the application of either of two formulae, the coastal State shall apply two constraints: A) Construction of the distance constraint line of $350 \mathrm{M}$ from baselines. B) Construction of the depth constraint line of $2500 \mathrm{~m}$ isobaths plus $100 \mathrm{M}$.

\section{THE APPLICATION OF THE CONSTRAINTS CONTAINED IN ARTICLE 76 (5) OF UNCLOS}

The extension of the continental shelf that may be claimed by a coastal State beyond $200 \mathrm{M}$ is subject to certain restrictions. In this sense, Article 76 (2) provides:

"The continental shelf of a coastal State shall not extend beyond the limits provided for in paragraphs 4 to $6 " 59$.

Paragraphs 4 to 6 provide for the application of two positive formulae (already discussed above) and two negative constraints, in different combinations, depending on the

\footnotetext{
57 Art. 76 (4) (b) UNCLOS.

58 Point 6.1.2. of the STG of the CLCS.

59 Art. 76 (2) UNCLOS.
} 
specific circumstances of each case. The combined result of these formulae and constraints determines the extent of the outer limits of the continental shelf.

The two constraints are set out in Article $76(5)^{60}$ :

"The fixed points comprising the line of the outer limits of the continental shelf on the seabed, drawn in accordance with paragraph 4 (a)(i) and (ii), either shall not exceed 350 nautical miles from the baselines from which the breadth of the territorial sea is measured or shall not exceed 100 nautical miles from the 2,500 metre isobath, which is a line connecting the depth of 2,500 metres".

Thus, the coastal State may choose to apply either of two constraint lines: A) The distance constraint line of $350 \mathrm{M}$ from baselines. B) The depth constraint line of 2,500 $\mathrm{m}$ isobaths plus $100 \mathrm{M}$. The outer envelope of the two constraint lines will determine the outer limit of the continental shelf. Hence, coastal States can be expected to opt for the constraint line that is less restrictive on its claim to an extended continental shelf.

The distance constraint line is fairly straightforward as it is constructed from the baselines from which the breadth of the territorial sea is measured. To this purpose, the coastal State shall submit charts or lists of coordinates that reflect the location of its baselines, according to Articles 5 and 16 of $\mathrm{UNCLOS}^{61}$.

With regard to the depth constraint, paragraph 5 states that it "shall not exceed 100 nautical miles from the $2,500 \mathrm{~m}$. isobaths".

The CLCS has recognized "that the $2,500 \mathrm{~m}$ isobaths is an essential feature for the implementation of Article 76. It serves as the basis for the application of one of the constraint rules to the formulae lines to produce the outer limits of the continental shelf" ${ }^{6}$.

The UNCLOS does not specify how the coastal State should apply the 2,500 m isobaths constraints, which may be a technically complex exercise. Indeed, according to the CLCS:

" $[\mathrm{t}]$ he selection of the most salient points along the $2,500 \mathrm{~m}$ isobaths for the purpose of delineating the $100 \mathrm{M}$ limit may be straightforward when isobaths are simple. However, when isobaths are complex or repeated in multiples, the selection of points along the 2,500 m isobath becomes difficult. Such situations arise as a result of geological and tectonic processes shaping the present continental margins. They can create multiple repetitions of the 2,500 isobath, for example, by faulting, folding and thrusting along continental margins. Unless there is evidence to the contrary, the Commission may recommend the use of the first $2,500 \mathrm{~m}$ isobaths from the baselines from which the breadth of the territorial sea is measured that conforms to the general configuration of the continental margin" ${ }^{63}$.

\footnotetext{
60 Art. 76 (5) UNCLOS.

61 Le SOURd (2017) pp. 624-652.

62 Point 4.1.1. of the STG of the CLCS.

${ }^{63}$ Point 4.4.2. of the STG of the CLCS.
} 
In this regard, the CLCS has adopted a bifurcation approach: "(1) when the isobaths are simple, the selection of 2,500-meter isobaths for the purpose of the construction of depth constraint lines is a straightforward operation; and (2) when the isobaths are complex or repeated in multiples, the Commission may, unless there is evidence to the contrary, recommend the use of the first 2,500-meter isobath that conforms to the general configuration of the continental margin" ${ }^{64}$.

\section{THE APPLICATION OF THE DEPTH CONSTRAINT IN SEAFLOOR HIGHS THAT ARE NATURAL COMPONENTS OF THE CONTINENTAL MARGIN}

As previously mentioned, the coastal State may choose to apply either of the two constraints established under Article 76 (5), whichever is more favorable to its claim. Depending on the geography of the natural prolongation of the submarine areas, this may be the $350 \mathrm{M}$ distance restriction or the $2,500 \mathrm{~m}$ isobaths depth restriction. However, paragraph 6, first sentence, contains an exception in case of submarine ridges, that are only susceptible to the $350 \mathrm{M}$ distance constraint:

"Notwithstanding the provisions of paragraph 5, on submarine ridges, the outer limit of the continental shelf shall not exceed 350 nautical miles from the baselines from which the breadth of the territorial sea is measured"65.

It should be borne in mind that the submarine ridges and the submarine elevations are part of the continental margin. This situation implies a geomorphologic continuity between the landmass of the coastal State and the seafloor high. Regarding the submarine ridges, the difference with the submarine elevations consist in that the "submarine ridges are simply components of the margin to which they belong"66, while the submarine elevations are natural components of the continental margin.

Then again, the second sentence of paragraph 6 establishes a counter-exception regarding submarine ridges, this time to "submarine elevations that are natural components of the continental margin":

"This paragraph does not apply to submarine elevations that are natural components of the continental margin, such as its plateaux, rises, caps, banks, and spurs" ${ }^{67}$.

Thus, the second sentence of paragraph 6 "revives" the applicability of paragraph 5, in particular, the coastal State's faculty to apply either the $350 \mathrm{M}$ distance, or the 2,500

\footnotetext{
64 KunOY et al. (2010) p. 363.

65 Art. 76 (6) UNCLOS.

66 GaO (2012) p. 129.

${ }^{67}$ Art. 76 (6) UNCLOS.
} 
$m$ isobaths depth constraints, to "submarine elevations that are natural components of the continental margin, such as its plateau, rises, caps, banks and spurs"68.

The wording of paragraph 6 is very complex and may be interpreted in different ways. The interpretation of Article 76 (6), in accordance with Article 31 of the VC, will have the following options:

a) The pivotal element is "submarine ridge". Thus, when the seafloor high is classified as a submarine ridge, the coastal State cannot apply paragraph 5 of Article 76.

b) The pivotal element is the phrase "submarine elevations that are natural components of the continental margin". Thus, whenever the submarine elevation is a natural component of the continental margin, the coastal State may apply paragraph 5. If the submarine elevation is not a natural component of the continental margin, the coastal State cannot apply paragraph 5, and the feature will be classified as a submarine ridge.

c) The pivotal element is "the natural component of the continental margin". Thus, whenever the seafloor high is a natural component of the continental margin, the coastal State may apply paragraph 5. However, if the coastal State cannot demonstrate that the seafloor high is a natural component of the continental margin, then the coastal State cannot apply paragraph 5 and the seafloor high will be classified as a submarine ridge ${ }^{69}$.

From our point of view, the defining element in the wording of this paragraph is "the natural component of the continental margin" (alternative C). Then, the enumeration of some features that can be classified as a natural component of the continental margin is not exhaustive, and any other feature of the seafloor high that is a natural component of the continental margin should be classified as a submarine elevation. Hence, the key to understand the application of this paragraph is the phrase "natural component of the continental margin".

The Commission held that "the term 'submarine elevations' in paragraph 6 includes a selection of highs: 'such as plateau, rises, caps, banks and spurs'. The phrase 'such as' implies that the list is not complete" 70 .

This means that submarine ridges are a special category of seafloor highs that are not "natural components of the continental margin". The Commission has recognized that the "Submarine ridges constitute a special case which is subject to the rules of entitlement given by paragraph 4 (a) and (ii), but it is also subject to the more stringent constraint provided by paragraph $6{ }^{\prime 71}$.

\footnotetext{
68 Art. 76 (6) UNCLOS.

69 The scholars BAUMERT and ROEST have done a similar exercise for the interpretation of Article 76 (6) of UN-

CLOS but with different conclusions. BAUMERT and RoEsT (2019).

70 Point 7.3.1. of the STG of the CLCS.

71 Point 2.1.10. of the STG of the CLCS.
} 
Supporting the previous ideas, professor Kunoy has stated that "the classification of a seafloor high as a submarine ridge or a submarine elevation serves the purpose of not only distinguishing it from an oceanic ridge, within the meaning of Article 76(3) of the Convention, but also determining whether the $2500-\mathrm{m}$ isobaths may be utilized as a basis for the depth constraint line for the purpose of establishing the outer limits of the continental shelf" 72 .

The fact that the seafloor high is considered as a submarine elevation and, therefore, a natural component of the continental margin, will be established on the basis of geological, geomorphological, and other scientific evidence, and not through pre-existing geographical denomination. In this sense, the CLCS has stated:

“The distinction between the 'submarine elevations' and 'submarine ridges' or 'oceanic ridges' shall not be based on their geographical denominations and names used so far in the preparation of the published maps and charts and other relevant literature. Such a distinction for the purpose of article 76 shall be made on the basis of scientific evidence taking into account the appropriate provisions of these Guidelines"73.

Hence, the scientific evidence will be the key for the classification of a seafloor high that is a natural component of the continental margin as a submarine elevation and not as a submarine ridge. According to the Commission the geology and geomorphology evidence will be important to demonstrate that a feature can be classified as a submarine elevation. The CLCS has also stated that " $\mathrm{t}]$ his makes it relevant to consider the processes that form the continental margins and how continents grow. The growth of the present continent is and/or was primarily caused by geological process along the continental margins" 74 . As a consequence, professor Kunoy concludes: "Hence, the Commission seems to base the classification of a seafloor high as a natural component of the continental margin on whether there is geological continuity" 75 .

Furthermore, according to the $\mathrm{VC}$, along with the interpretation of Article 31, the application of Article 32 could also be important. Article 32 of the VC is entitled "Supplementary Means of Interpretation". Customary treaty interpretation rules allow recourse to supplementary means of interpretation, including the preparatory work of the treaty and the circumstances of its conclusion, "in order to confirm the meaning resulting from the application of article 31 , or to determine the meaning when the interpretation according to article 31: (a) leaves the meaning ambiguous or obscure; or (b) leads to a result which is manifestly absurd or unreasonable"76.

72 Kunoy (2012) pp. 118-119.

73 Point 7.1.8. of the STG of the CLCS.

74 Point 7.3.1. of the STG of the CLCS.

75 Kunoy (2012) p. 119.

76 Article $32 \mathrm{VC}$. 
In the context of the Third United Nations Conference on the Law of the Sea, we can find that the USSR made two important proposals regarding this issue. In the eight session, "[t]he USSR submitted a new proposal stating that submarine ridges shall not extend farther than a 350 mile distance" 77 . In the following session, the USSR made a second proposal about this topic, where it stated that the continental shelf, for paragraph 3 , "should 'not include the deep ocean floor, with its oceanic ridges, seamounts, guyots and any other submarine elevations not situated on the continental margin, or the subsoil of the ocean floor'. For paragraph 5, the USSR proposed to add a new paragraph 5 bis:

"Notwithstanding the provisions of paragraph 5, in areas of any other submarine ridges and elevations except those referred to in paragraph 3 of this Article, the outer limits of the continental shelf shall not exceed 350 nautical miles from the baselines from which the breadth of the territorial sea is measured'"78.

From these proposals, the only clear one is the idea that the submarine ridges cannot exceed $350 \mathrm{M}$ and also any other elevation located off the continental margin.

Finally, during the ninth session, the "Group of Margineers" presented the following proposal for paragraph 3:

"The continental margin comprises the submerged prolongation of the land mass of the coastal state, and consists of the seabed, the submarine elevations and the subsoil of the shelf, the slope and the rise. It does not include the deep ocean floor with its oceanic ridges or the subsoil thereof" 79 . Suárez states that there was a similar proposal from Australia, "except that it added the phrase "which are natural components of the continental margin, such as plateaux, rises, banks and spurs" in reference to submarine elevations" $"$.

Notwithstanding, the travaux préparatoires give no other information that can be used to understand paragraph 6 of Article 76. In this sense, professor Alex Oude Elferink commented that " $[\mathrm{t}]$ he travaux préparatoires of Article 76 furthermore indicate that the provision concerning submarine ridges was among other things intended to prevent that islands situated on oceanic ridges would have a continental shelf beyond 350 nautical miles. This latter aspect of Article 76(6) seems to have been lost from sight in the elaboration of Article 76 in the Scientific and Technical Guidelines of the Commission" ${ }^{81}$. In addition, "[a]s the result of a negotiated compromise, the relevant provisions of the LOS Convention do not define the three kinds of seafloor highs" $\$ 2$.

\footnotetext{
SuAREZ (2008) pp. 62-63.

78 SuAREZ (2008) p. 65.

79 Suarez (2008) p. 64.

80 Suarez (2008) p. 65.

81 Oude Elferink (2009a) p. 129.

82 GAO (2012) p. 120.
} 
In the case between Eritrea and Yemen, the Arbitral Tribunal pointed out that: "In any event there has to be room for differences of opinion about the interpretation of articles which, in a last minute endeavor at the Third United Nations Conference on the Law of the Sea to get agreement on a very controversial matter, were consciously designed to decide as little as possible" 83 .

This passage of the Arbitral Award is commented by Judge Gao in the following terms: "These observations are applicable to the seafloor high provision of Article 76, which were included in the provision at a late stage of the Third United Nations Conference on the Law of the Sea (Third Conference)" 84 .

We must now turn our attention on Article 31 (3) of the VC. In the light of this Article, the subsequent practice of the States and the CLCS gains relevance for the proper interpretation of Article 76 (6).

\section{CLCS AND THE INTERPRETATION OF PARAGRAPH 6 OF ARTICLE 76}

\section{The CLCS AND THE SUbSEQUENCE PRACTICE}

The CLCS is a technical commission and is not an adjudicative body. It does not decide on the delimitation of the continental shelf between States with opposite or adjacent coasts (Article 76 [10]).

The CLCS's recommendations are also not declarative of the costal State's rights over the continental shelf. Article 77 (3) confirms that the coastal State's rights over the continental shelf (up to $200 \mathrm{M}$ or extended) are ipso facto and $a b$ initio $^{85}$. Article 77 (3) provides:

"The rights of the coastal State over the continental shelf do not depend on occupation, effective or notional, or on any express proclamation" ${ }^{\prime 6}$.

This ambiguous task of the CLCS cannot be confused with a judicial aspect of its tasks. The role of the Commission is to assess and legitimate the scientific information submitted by the coastal States to prove their entitlement to an extended continental shelf. Hence, the role of the Commission is neither adjudicative nor declarative of the coastal State's rights over the continental shelf. Its function is limited to reviewing, evaluating and legitimating ${ }^{87}$ the scientific information submitted, in accordance with the dispositions of Article 76. Even so, it is evident that it must inevitably engage in the interpretation of Article 76 to issue its recommendations.

\footnotetext{
83 ERITREA V. YEMEN (1999) para. 116.

${ }^{84}$ GAO (2012) p. 121.

85 GERMANY V. DENMARK; GERMANY V. NETHERLAND (1969) para. 19.

86 Art. 77 (3) UNCLOS.

87 "Legitimation is not the same thing as legal or political approval. Moreover, legitimation must be understood not in terms of black and white (legitimate or illegitimate) but as a spectrum between greater legitimacy and lesser legitimacy". McDorman (2002) p. 319.
} 
To "clarify its interpretation of scientific, technical and legal terms contained in the Convention" "88, the Commission has issued the Scientific and Technical Guidelines of the Commission on the Limits of the Continental Shelf (STG).

The legal status of these guidelines for the interpretation of the treaty poses a valid question under Article 31 (3) of the VC. This Article establishes as follows:

"There shall be taken into consideration together with the context:

a) Any subsequent agreement between the parties regarding the interpretation of the treaty or the application of its provisions;

b) Any subsequent practice in the application of the treaty which establishes the agreement of the parties regarding its interpretation;

c) Any relevant rules of international law applicable in the relations between the parties" $"$.

In a first approach, the guidelines could be considered as a subsequent agreement, according to Article 31 (3) (a) of the VC. However, the STG could not be classified as a subsequent agreement between the parties of UNCLOS because the parties were not responsible in the elaboration of the guidelines. Maybe, the guidelines could be classified as a subsequent practice in the application of the treaty. But the STG were elaborated by an expert body. Hence, it could be held that the STG are not a subsequence practice under Article 31 (3) (b) of the VC. Conclusion 5 (2) of the Draft conclusions on subsequent agreements and subsequent practice in relation to the interpretation of treaties adopted by the International Law Commission (DSASP) states that: "Other conduct, including by non-State actors, does not constitute subsequent practice under articles 31 and 32. Such conduct may, however, be relevant when assessing the subsequent practice of parties to a treaty" ${ }^{\circ}$. It is true that the CLCS is a "non-State actor" but the subsequence practice by the States and the sui generis legal status of these guidelines support the thesis that the STG have promoted a subsequence practice of the States parties of UNCLOS, in accordance with Article 31 (3) (b) of the VC in the interpretation of Article 76. Thus, the guidelines play an important role in the interpretation of Article 76 of UNCLOS.

On the other hand, the CLCS is an expert body and in accordance with the conclusion 13, paragraph 3, related to the "Pronouncements of expert treaty bodies" of the DSASP "[a] pronouncement of an expert treaty body may give rise to, or refer to, a subsequent agreement or subsequent practice by parties under article 31, paragraph 3, or subsequent practice under article 32 . Silence by a party shall not be presumed to constitute subsequent practice under article 31, paragraph $3(b)$, accepting an interpretation of a treaty as expressed in a pronouncement of an expert treaty body" ${ }^{\prime 1}$.

\footnotetext{
88 Point 1.3. of the STG of the CLCS.

89 Art. 31 (3) VC.

90 DSASP, conclusion 5 (2).

91 DSASP, conclusion 13.
} 
It is important to bear in mind that a pronouncement of the CLCS is not a subsequence agreement or practice in accordance with Article 31 (3) (a) or (b) of the $\mathrm{VC}^{92}$. This is confirmed in the commentaries to the DSASP when they state that "[a] pronouncement of an expert treaty body cannot as such constitute a subsequent agreement or subsequent practice under article 31, paragraph 3 (a) or (b), since this provision requires an agreement of the parties or subsequent practice of the parties that establishes their agreement regarding the interpretation of the treaty" ${ }^{\prime 3}$.

Therefore, we have that the STG should be considered as an important element in the subsequence practice of the States parties of UNCLOS in the interpretation of Article 76 in accordance with Article 31 (3) (b) of the VC, and the importance of the subsequence practice in the context of the CLCS's recommendations (for this paper) is the subsequence practice of the States which submit information according to the opinions and guidelines of the CLCS in order to interpret Article 76 (6) of UNCLOS ${ }^{94}$.

\section{The CLCS and its Recommendations with mention of Article 76 (6)}

With regard to the depth constraint and its application in accordance with Article 76 (6), the CLCS has regularly included the following sentence in its recommendations:

"Alternatively, the provision that the outer limits of the continental shelf may not exceed $100 \mathrm{M}$ distance from the $2500 \mathrm{~m}$ isobath (the depth criterion constraint) may be applied for those parts of the continental margin that are classified as natural components of that margin"95.

Similarly, in its recommendation on France's submission regarding New Caledonia, the CLCS stated as follows:

"Alternatively, the provision that the outer limits of the continental shelf may not exceed $100 \mathrm{M}$ from the $2500 \mathrm{~m}$ isobath ("the depth constraint") may be applied to those parts of the continental margin that are classified as natural components of that margin" 96 .

These statements support the thesis of this paper, namely, that the pivotal element in paragraph 6 of Article 76 is that the seafloor high is a natural component of the continental margin. Thus, if the coastal State can prove that the seafloor high is a natural component of the continental margin, the feature will be classified as a submarine elevation and the State can apply both constraints.

\footnotetext{
92 JENSEN (2015) p. 593-595.

93 DSASP, conclusion 13 (9).

94 This subsequence practice of the States in the interpretation of Article 76 (6) could be considered as a subsequence practice under Article 32 of the VC.

95 Recommendations of the CLCS in Regard to the Submission Made by Australia, para.102.

96 Recommendations of the CLCS in regard to the Submission made by France in respect of French Guiana and New Caledonia Regions, para. 34.
} 
A special situation occurred in the procedure concerning the submission of Iceland on the Reykjanes Ridges. In this case, the Subcommission accepted that the Reykjanes Ridge was a natural component of the continental margin, and Iceland could use both constraints: "The prevalent view in the Subcommission was that the depth constraint is the applicable constraint in the western and southern parts of the Reykjanes Ridge. It agreed with the procedure and methods applied by Iceland in the construction of this constraint line, based on the $2500 \mathrm{~m}$ isobath along selected multi-beam bathymetric profiles"97. When the procedure reached the Commission, the CLCS confirmed its position stating: "Alternatively, the provision that the outer limits of the continental shelf may not exceed $100 \mathrm{M}$ from the $2500 \mathrm{~m}$ isobath ('depth constraint') may be applied to those parts of the continental margin that are classified as natural components of that margin"98.

However, the Commission held a different view with respect to the application of the depth constraint in this particular case: "The Commission could not arrive at the conclusion that the depth constraint line was applicable, and considered that the data and information contained in the Submission were inconclusive to support the western and southern parts of the Reykjanes Ridge as a natural component of the continental margin of Iceland. For this reason, the Commission decided to recommend only on those fixed points constituting the outer limits of the continental shelf that are located within $350 \mathrm{M}$ from the baselines from which the breadth of the territorial sea of Iceland is measured"99.

It is important to point out that neither the Subcommission nor the Commission attached any relevance to the name of the feature, "Reykjanes Ridge", in order to determine whether this seafloor high was a seafloor ridge, in the sense of the first sentence of paragraph 6 , or a natural component of the continental margin, in the sense of the second sentence of paragraph 6. Both institutions based their (opposite) conclusion on scientific data only.

A different case was presented by the submission of Norway in regard to Bouvetøya. Norway classified the Shaka Ridge as a submarine elevation that is a natural component of the continental margin. The Commission stated:

"For the outer limits of the continental shelf in the Bouvetøya region, Norway has invoked a combination of the distance and the depth constraints. In the vicinity of Bouvetøya, consideration of the outer limits of the continental shelf only involves an examination of the construction of the distance constraint line. However, in the vicinity of the Shaka Ridge, consideration of the outer limits also involves consideration of the application of the depth constraint (Figure 14). In the view of the Commission, the application of the depth constraint involves the examination of whether

\footnotetext{
${ }_{97}$ Recommendations of the CLCS in regard to the Submission made by Iceland in the Ægir Basin Area and in the Western and Southern parts of Reykjanes Ridge, para. 77.

${ }_{98}$ Recommendations of the CLCS in regard to the Submission made by Iceland in the Ægir Basin Area and in the Western and Southern parts of Reykjanes Ridge, para. 73.

99 Recommendations of the CLCS in regard to the Submission made by Iceland in the Ægir Basin Area and in the Western and Southern parts of Reykjanes Ridge, para. 78.
} 
the relevant seafloor high, the Shaka Ridge, may be considered a natural component of the continental margin" 100 .

In first instance, the Subcommission was not convinced about the nature of Shaka Ridge as a submarine elevation in the sense of paragraph $6^{101}$. After Norway had submitted additional data that supported its thesis, the Subcommission concluded that "[a]s a result of the geochemical nature of the samples from Shaka Ridge falling within the trace element envelope of those from the Bouvetøya Pedestal, the majority of the Subcommission agreed that the Shaka Ridge is a submarine elevation in the sense of paragraph 6 of article 76 of the Convention" 102

The Commission reached the same conclusion and stated that the "majority of members of the Commission is in agreement with Norway that the Shaka Ridge is a submarine elevation in the sense of paragraph 6 of article 76. The Commission agrees with Norway that the depth constraint of $100 \mathrm{M}$ seaward of the $2,500 \mathrm{~m}$ isobath is an applicable constraint on the Shaka Ridge, and agrees with the methodology and its accuracy applied by Norway in the construction of this constraint line"103.

Again, this confirms that the geographical denomination of a seafloor high, historically known as a "ridge" is not relevant to the Commission's recognition as a natural component of the continental margin. If scientific evidence is provided that demonstrates that the seafloor high can be classified as a natural component of the continental margin, the coastal State can apply both constraints contained in paragraph 5 of Article 76.

\section{CONCLUSION}

The definition of continental shelf contained in Article 76 (1) establishes two criteria for entitlements of the coastal States on the continental shelf: distance or natural prolongation ${ }^{104}$. When the natural prolongation of its submerged land territory to the outer edge of the continental margin extends beyond $200 \mathrm{M}$ the coastal State is entitled to claim an extended continental shelf on the basis of operative rules contained in Article 76 (4-10) ${ }^{105}$.

Hence, the natural prolongation is not a vague concept and is the raison d'etre of the coastal State's rights on the outer continental shelf. Furthermore, "[t] he concept of natural prolongation in Article 76 is decisive for the purpose of the distinction of the three types of

\footnotetext{
100 Recommendations of the CLCS in regard to the Submission made by Norway in respect of Bouvetøya and Dronning Maud Land, para. 61.

101 Recommendations of the CLCS in regard to the Submission made by Norway in respect of Bouvetøya and Dronning Maud Land, para. 66.

102 Recommendations of the CLCS in regard to the Submission made by Norway in respect of Bouvetøya and Dronning Maud Land, para. 68.

103 Recommendations of the CLCS in regard to the Submission made by Norway in respect of Bouvetøya and Dronning Maud Land, para. 71.

104 Art. 76 (1) UNCLOS.

105 Art. 76 (4-10) UNCLOS.
} 
seafloor highs" ${ }^{106}$. If the seafloor high is part of the continental margin of the coastal State's submerged prolongation of the land mass, it will be classified as a submarine ridge or submarine elevation. But if the seafloor high is not part of the continental margin, it will be an oceanic ridge and the State cannot use that feature for the establishment of the outer limits of the continental shelf. The establishment of the outer limits of the continental shelf shall be done in the light of the different rules given in Article 76.

For the establishment of the outer limits of the continental shelf the coastal State shall apply two positive rules (formulae) and two negative rules (constraints).

In the context of the two constraints, the coastal State shall apply a distance constraint of $350 \mathrm{M}$ from the baselines; or the 2,500 m isobaths plus $100 \mathrm{M}$. Regarding the isobaths constraint, Article 76 (6) establishes an exception and a counter exception. The exception is that the coastal State cannot apply the depth constraint when the seafloor high is a submarine ridge. And the counter exception is that the coastal State can apply both constraints when it demonstrates that its seafloor high is a natural component of the continental margin, in which case the seafloor high will be classified as a submarine elevation that is a natural component of the continental margin.

The isobath constraint has been subject to an important development in State practice and, most importantly, the practice of the CLCS. The pivotal element for the CLCS and in State submissions has been whether the seafloor high is a natural component of the continental margin. This will be established on the basis of scientific evidence provided by the coastal State. If the evidence fails to demonstrate that the seafloor high is a natural component of the continental margin, the CLCS will classify the seafloor high feature as a submarine ridge and the exception of paragraph 6, first sentence, will apply. As a consequence, the coastal State can only apply the $350 \mathrm{M}$ distance constraint and not the 2,500 isobaths depth constraint to establish the outer limits of its continental shelf.

Finally, the interpretation of paragraph 6 of Article 76, with the rest of Article 76, shows the complex and hybrid function of the Commission in the development of the law of the sea. Even though this is a technical and scientific institution, it is impossible to dismiss its role in the development of the international law of the sea.

\section{BIBLIOGRAPHY}

BASARAn, Ilker (2015): "The Lomonosov Ridge and the Overlapping Outer Continental Shelf Claim to North Pole", Journal of Maritime Law and Commerce, vol. 46, No. 1: pp. 1-22.

Baumert, Kevin and Roest, Walter (2019): "Submarine Elevations and Submarine Ridges under Article 76". See the presentation at ABLOS Conference 2019. Available in: https://iho.int/en/ablos10-conference-2019. Consulted: January 21, 2020.

Colson, David (2003): "The Delimitation of the Outer Continental Shelf between Neighboring States", The American Journal of International Law, vol. 97, No. 1: pp. 91-107.

${ }^{106}$ GAO (2012) p. 136. 
Evans, Malcolm (2018): "Relevant Circumstances", in Oude Elferink, Alex; Henriksen, Tore, and Veierud, Signe (edits.), Maritime Boundary Delimitation: The Case Law (Cambridge: Cambridge University Press) pp. 222-261.

GaO, Jianjun (2012): "The Seafloor High Issue in Article 76 of the LOS Convention: Some Views from the Perspective of Legal Interpretation”, Ocean Development \& International Law, vol. 43: pp. 119-145.

GesLin, Albane (2018): "La Jurisprudence du Tribunal International du Droit de la Mer en Matière de Délimitations Maritimes", in Le Floch, Guillaume (edit.), Les Vingt Ans du Tribunal International du Droit de la Mer (París: Editions A. Pedone) pp. 207-221.

Huang, Yao and Liao, Xuexia (2014): "Natural Prolongation and Delimitation of the Continental Shelf beyond $200 \mathrm{~nm}$ : Implications of the Bangladesh/Myanmar Case", Asian Journal of International Law, vol. 4: pp. 281-307.

Jensen, Oystein (2015): "Maritime Boundary Delimitation beyond 200 Nautical Miles: The International Judiciary and the Commission on the Limits of the Continental Shelf", Nordic Journal of International Law, vol. 84, No. 4: pp. 580-604.

Jensen, Oystein (2018): "The Delimitation of the Continental Shelf beyond 200nm" in Oude Elferink, Alex, Henriksen, Tore, and Veierud, Signe (edits.), Maritime Boundary Delimitation: The Case Law (Cambridge: Cambridge University Press) pp. 351-375.

Kunoy, Bjorn; Heinesen, Martin; and Mork, Finn (2010): "Appraisal of Applicable Depth Constraint for the Purpose of Establishing the Outer Limits of the Continental Shelf", Ocean Development \& International Law, vol. 41: pp. 357-379.

Kunoy, Bjorn (2011): "Establishment of the Outer Limits of the Continental Shelf: Is Crossing Boundaries Trespassing", The International Journal of Marine and Coastal Law, vol. 26: pp. 313-334.

Kunoy, Bjorn (2012): "The Terms of Reference of the Commission on the Limits of the Continental Shelf: A Creeping Legal Mandate", Leiden Journal of International Law, vol. 25: pp. 109-130.

Kunoy, Bjorn (2013): “The Delimitation of an Indicative Area of Overlapping Entitlement to the Outer Continental Shelf", The British Yearbook of International Law, vol. 83, No. 1: pp. 61-81.

LE Sourd, Guillaume (2017) : "L'information géographique et la Convention des Nations Unies sur le Droit de la Mer: Considérations Techniques et Pratiques des États Côtiers”, in Thouvenin, Jean Marc and Forteau, Mathias (edits.), Traité de Droit International de la Mer (París, Editions A, Pedone) pp. 624-652.

Magnússon, Bjarni (2013): "Outer Continental Shelf Boundary Agreements", International and Comparative Law Quarterly, vol. 62, Issue 02: pp 345-372.

Magnusson, Bjarni (2013a): "Is There a Temporal Relationship between the Delineation and the Delimitation of the Continental Shelf beyond 200 Nautical Miles", International Journal of Marine and Coastal Law, vol. 28, No. 3: pp. 465-484.

Magnússon, Bjarni (2014): "The Rejection of a Theoretical Beauty: The Foot of the Continental Slope in Maritime Boundary Delimitations beyond 200 Nautical Miles", Ocean Development and International Law, vol. 45, No. 1: pp. 41-52. 
McDorman, Ted (2002): "The Role of the Commission on the Limits of the Continental Shelf: A Technical Body in a Political World", The International Journal of Marine and Coasal Law, vol. 17, No. 3: pp. 301-324.

Mossop, Joanna (2016): The Continental Shelf Beyond 200 Nautical Miles (Oxford: Oxford University Press).

Oude Elferink, Alex (2006): "Article 76 of the LOSC on the Definition of the Continental Shelf: Questions concerning Its Interpretation from a Legal Perspective", The International Journal of Marine and Coastal Law, vol. 21, No. 3: pp. 269-285.

Oude Elferink, Alex (2009): "The Establishment of Outer Limits of the Continental Shelf beyond 200 Nautical Miles by the Coastal State: The Possibilities of Other States to Have an Impact on the Process", International Journal of Marine and Coastal Law, vol. 24, No. 3: pp. 535-556.

Oude Elferink, Alex (2009a): "The continental shelf in the polar regions: cold war or black-letter law?", Netherlands Yearbook of International Law, vol. 40XL: pp. 121-181.

SuAREZ, Suzette (2008): The Outer Limits of the Continental Shelf: legal aspects for their establishment (Heidelberg: Max Planck Institute).

TanaKa, Yoshifumi (2012): The International Law of the Sea (Cambridge: Cambridge University Press).

Von Muhlendahl, Paul (2016): L`Équidistance dans la Délimitation des Frontières Maritimes: Étude de la jurisprudence international (Paris: Editions A. Pedone).

\section{LEGAL INSTRUMENTS}

Vienna Convention on the Law of the Treaties (May 23, 1969).

United Nations Convention on the Law of the Sea (December 10, 1982).

Scientific and Technical Guidelines of the Commission on the Limits of the ContiNENTAL SHELF. CLCS/ 11(May 13, 1999)

\section{JUDGMENTS AND AWARDS}

InTERnATional Court of Justice:

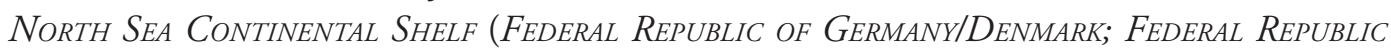
of GERMANY/NETHERLANDS), International Court of Justice, I.C.J. Reports 1969.

Aegean Sea Continental Shelf (Greece V. Turkey), International Court of Justice, I.C.J. Reports 1978.

Continental SheLf (Tunisia/Libyan ARAB JAMahiriya), International Court of Justice, I.C.J. Reports 1982.

Continental Shelf (Libyan Arab Jarnahiriya/Malta), International Court of Justice, I.C.J. Reports 1985.

Maritime Delimitation in the Black Sea (Romania v. UkRaine), International Court of Justice, I.C.J. Reports 2009. 
Territorial and Maritime Dispute (Nicaragua v. Colombia), International Court of Justice, I.C.J. Reports 2012.

Maritime Dispute (Peru V. Chile), International Court of Justice, I.C.J. Reports 2014.

Question of the Delimitation of the Continental Shelf between Nicaragua and Colombia beyond 200 Nautical Miles from the Nicaraguan Coast (Nicaragua V. Colombia), International Court of Justice, I.C.J. Reports 2016.

Maritime Delimitation in the Indian OcEan (Somalia v. KenYa), International Court of Justice, I.C.J. Reports 2017.

INTERnational Tribunal FOR THE LAW OF THE SEA

Delimitation of the MaRitime boundary in the BAy of BENGAL (BANGLADESH V. MYANMAR), International Tribunal for the Law of the Sea, ITLOS Reports 2012.

Dispute concerning Delimitation of the Maritime Boundary Between Ghana and Côte D'IVOIRE IN THE ATLANTIC OCEAN (GHANA V. COTE D'IVOIRE), International Tribunal for the Law of the Sea, ITLOS, 2017.

\section{Arbitral Tribunals}

ERITREA V. YEMEN, Award of the Arbitral Tribunal in the second stage of the proceedings (maritime delimitation) 1999.

BARBADOS V. TRINIDAD AND TOBAGO, Arbitral Award, 2006.

\section{RECOMMENDATIONS ADOPTED BY THE CLCS}

Recommendations of the Commission on the Limits of the Continental Shelf (CLCS) in Regard to the Submission Made by Australia on 15 November 2004. Adopted by the Commission on 9 April 2008.

Summary of Recommendations of the Commission on the Limits of the Continental Shelf in regard to the Submission made by France in respect of French Guiana and New Caledonia Regions on 22 May 2007. Adopted by the Commission on 2 September 2009.

Summary of Recommendations of the Commission on the Limits of the Continental Shelf in regard to the Submission made by the United Kingdom of Great Britain and Northern Ireland in respect of Ascension Island on 9 May 2008. Adopted by the Commission, with amendments, on 15 April 2010.

Summary of Recommendations of the Commission on the Limits of the Continental Shelf in regard to the Submission made by Iceland in the Ægir Basin Area and in the Western and Southern parts of Reykjanes Ridge on 29 April 2009. Approved by the Commission, with amendments, on 10 March 2016.

Summary of Recommendations of the Commission on the Limits of the Continental Shelf in regard to the Submission made by Norway in respect of Bouvetøya and Dronning Maud Land on 4 May 2009. Approved by the Commission, with amendments, on 8 February 2019. 


\section{REPORTS ADOPTED BY THE ILC}

Draft conclusions on subsequent agreements and subsequent practice in relation to the interpretation of treaties. Adopted by the International Law Commission at its seventieth session, in 2018. Yearbook of the International Law Commission, 2018, vol. II, Part Two.

Draft conclusions on subsequent agreements and subsequent practice in relation to the interpretation of treaties, with commentaries. Adopted by the International Law Commission at its seventieth session, in 2018. Yearbook of the International Law Commission, 2018, vol. II, Part Two. 
